\title{
Management of Entrepreneurship Mentoring of Local Potential (Coconut Shell) of Mosque-Based Posdaya (Family Empowerment Post)
}

\author{
M. Fahim Tharaba ${ }^{1 *}$, Nurul Yaqien ${ }^{2}$, Rosida Kerin Meirani ${ }^{3}$ \\ 1, 2, 3 Universitas Islam NegeriMaulana Malik Ibrahim Malang, Indonesia \\ "Corresponding author. Email: fahim.uinmaliki@gmail.com
}

\begin{abstract}
The development of plantation agroindustry is very important effort to attract and encourage the emergence of new industries in the agricultural sector, also to create a resilient economic structure, added value of a product, jobs, and increase foreign exchange receipts. Coconut shell agroindustry is one of agroindustry mostly attempted on a household scale, so it has not been able to play a maximum role. This research took the village of Wager and Sukosari, located in Kasembon sub-district as the locus. This participatory action research is done through four stages, namely: (1) Planning (2) Action (3) Observation (4) reflection. After this action research is applied, there are some change, namely: (1) Added value and profit to coconut shell agro-industrial products. (2) Availability and skilled human resources. (3) Increased knowledge of management in running a business. (4) Increased knowledge of the importance of competitive excellence, marketing and sales, service, technology development, human resources management, and infrastructure. (5) The creation of an established life. (6) The creation of a happy, loving and supportive family.
\end{abstract}

Keywords: Local Potential, Mosque-Based, Entrepreneurship Management

\section{INTRODUCTION}

Agro-industrial development is a continuation of agricultural development [1]. This has been proven that agro-industry is able to increase the income of agribusiness actors, able to absorb labor, able to increase foreign exchange acquisition, and able to encourage the emergence of other industries. Agro-industrial development is very important effort to achieve several objectives, namely attracting and encouraging the emergence of new industries in the agricultural sector, creating a resilient economic structure, creating added value, creating jobs, and increasing foreign exchange receipts [2].

Agro-industries that are expected to increase the income of agribusiness actors are agro-plantation industries. This is given that agro-industrial plantations are relatively directly connected to farming. One of the agro-industry plantations which existence has gained a place in the society is agroindustry that processes coconut shells taken from coconut trees. The coconut shells are processed to be craft.

Coconut is one of the most common agricultural commodity crops in Indonesia. This plant belongs to the palmae family or palms and thrives in temperate to hot climates. The coconut commodity is considered very beneficial for the community with all its forms of diversification. Coconut plant has many benefits, from roots to its stems. Coconut roots can be used for crafts, and firewood; coconut trunks can be made for building materials or various kinds of handicraft products such as water furniture, wall hangings, and various other crafts; coconut flowers that are called manggar and mancung can be used for various kinds of handicraft products, such as wall hangings, and firewood; the meat of the coconut can be processed into copra for the needs of the coconut oil industry, srondeng (Indonesian traditional food made from grated coconut and fried until golden brown with specific spices), pon pon mendut (Indonesian traditional snack which the filling is made from grated coconut mixed with brown sugar), coconut milk or coconut meal and other products made from the meat of coconut; coconut water can be used for various kinds of processed food or food ingredients like iced young coconut and nata de coco. Consuming coconut water or extract of coconut water is also very good for health of which can maintain the body's metabolism, prevent stroke, treat poisoning, and maintain stamina of body and kidneys, and even increase the health of the fetus. Next, the coconut skin or 
especially the husk can be used for various kinds of handicraft products, such as wall hangings, doormats, brooms, and firewood. The last is the shell of the coconut can be used for various kinds of handicraft products, such as wall hangings, water scoops, cups, saucers, key chains, beads, coconut embryos in scouts and firewood [3].

In its development, coconut produced a lot of waste, one of which is coconut shell. Processed coconut shell waste is considered more profitable than selling only raw coconut shells. So the efforts of farmers in the agroindustry to diversify the processed coconut shell into coconut handicrafts have a very important role in increasing income and business opportunities and potential to be developed. The coconut shell itself is a coconut shell which becomes waste from the coconut fruit.

Coconut shell agro-industry is one form of agroindustry which is mostly operated on a household scale. So that the coconut shell agro-industry has not been able to play a maximum role.

According to information from the DMI (Indonesian Mosque Council) Kasembon District and also the mosque-based Posdaya volunteer, Avicena, the number of coconut shells in Wager Hamlet, Sukosari Village, Kasembon District, is very abundant. It is estimated that each house has a pile of coconut shells on a truck and there are around 200 families, which only opened split the coconut shells and sold directly to middlemen. Therefore, with the increase in processed coconut shell handicrafts, it is hoped that it can encourage the development of coconut shell agro-industries. So that it can increase the profits of this coconut shell producer later. However, the agro-industry is experiencing obstacles, namely coconut shell producers find it difficult to improve the quality and quantity of coconut shell production and marketing.

In Malang Regency, especially in Wager Hamlet, Sukosari Village, Kasembon District, the coconut shell agro-industry is expected to develop due to the availability of abundant natural resources of coconut shells as raw material for the manufacture of processed coconut handicrafts. According to Anonymous [4], the Malang Regency government determines coconut as a raw material for potential superior products that can improve the economy in the Malang Regency. It can be seen from the number of home industries that use derivatives from coconut as raw material, namely coconut sugar. The use of coconut sugar is around 9,142 business units, where in the central area there are 8,818 business units and 324 business units in non-central areas. The production of printed coconut sugar in each area reaches around 40-50 tons per day, not yet other processed coconut products. This data shows how coconut is the main priority, which of course the waste, including coconut shells, is also the same.

However, in developing coconut shell agroindustry, it is still faced with several obstacles, such as limited capital, limited skills of the workforce, and lack of management knowledge in running a business. This indirectly causes the quantity and quality of coconut shell production to be low so that the profit obtained by coconut shell producers is low.

Based on the above circumstances, it is necessary to carry out action research in the context of developing coconut shell agro-industries to increase the income of coconut shell producers, so that later coconut shell agroindustries can be developed more advanced. Therefore, the development of coconut shell agro-industry in Wager Hamlet, Sukosari Village, Kasembon District, Malang Regency, needs to be carried out as a moral responsibility of higher education in the context of community service and development around the campus. It encourages and ignites to play a real role in all aspects of life [5].

\section{METHODS}

In order to increase the income of coconut shell producers with this coconut shell agro-industry, will use the Participation Action Research (PAR) method. This method is used in order to: 1) Overcoming the existing problems, namely the low productivity of the coconut shell agro-industry, 2) Supporting the community's desire to develop by knowing the activities that become competitive advantages in the agro-industry in the context of developing coconut shell agro-industries to increase their income, so that later the coconut shell agroindustry can be developed even further, 3) Developing strategies and methods to solve problems in the assisted area, and 4) Helping the community overcome, solve, and find solutions.

\section{RESULT AND DISCUSSION}

\subsection{The Locus of the Empowerment of Coconut Shell, Wager Hamlet, Sukosari Village, Kasembon District, Malang Regency}

This study chose Wager Hamlet, Sukosari Village, Kasembon District because that area is the largest supplier of coconut shells. According to information from the DMI (Indonesian Mosque Council) Kasembon District and also the mosque-based Posdaya volunteer, Avicena, The number of coconut shells in Wager Hamlet, Sukosari Village, Kasembon District, is very abundant. It is estimated that each house has a pile of coconut shells on a truck and there are around 200 families, which only opened split the coconut shells and sold directly to middlemen. 
In addition, coconut shell agro-industry in the area is still being cultivated on a household scale and the production process is still done traditionally. So that the quantity and quality of coconut shell production is still low. In fact, the demand for coconut shells from household and industrial consumers continues to increase along with the increasing population and the development of the industrial sector.

In this case what causes the quantity and quality of coconut shell production to be produced is still low, that is, it is known from several activities in the coconut shell agro-industry such as operational activities, human resource management activities and business financial activities. For operational activities in producing coconut shells, producers do not diversify their products. Each manufacturer only produces one kind of product in common with other manufacturers. This is because the producers are satisfied with the coconut shell products they produce.

For human resource management activities, the existing workforce tends to only do the work assigned to it without any desire to be able to create product diversification. So that coconut shell producers find it difficult to improve the quality of the resulting production. Meanwhile, in business financial activities, the capital used is still limited because in general coconut shell producers still rely on their own capital to run their business. With this limited capital, it is difficult for producers to increase the quantity of coconut shell production, so that it can affect the profits obtained by coconut shell producers.

Based on the description above, in general the problem in Wager Hamlet, Sukosari Village, Kasembon District is the low productivity of the coconut shell agroindustry so that the level of profit received by coconut shell producers is lower. Even though this coconut shell agro-industry has the potential to be developed by taking into account the conditions in the agro-industry.

As explained above, the quality of coconut shell production is still low. This is known from several activities in the coconut shell agro-industry in the assisted subjects, such as operational activities, human resource management and business financial activities. For operational activities in producing coconut shells, producers do not diversify their products. Each manufacturer only produces one kind of product in common with other manufacturers. This is because the producers are satisfied with the coconut shell products they produce. For human resource management activities, the existing workforce tends to only do the work assigned to it without any desire to be able to create product diversification. So that coconut shell producers find it difficult to improve the quality of the resulting production. Meanwhile, in business financial activities, the capital used is still limited because in general coconut shell producers still rely on their own capital to run their business. With this limited capital, it is difficult for producers to increase the quantity of coconut shell production, so that it can affect the profits obtained by coconut shell producers.

Thus, it can be concluded, in general, the conditions in the assisted subjects, namely Wager Hamlet, Sukosari Village, Kasembon District are

1. Coconut shells in Wager Hamlet, Sukosari Village, Kasembon District are very abundant

2. Coconut shells are only split open and sold directly to middlemen.

3. Coconut shell agro-industry in the area is still being cultivated on a household scale and the production process is still done traditionally.

4. The quality of coconut shell production is still low.

5. Several activities in the coconut shell agro-industry in the assisted subjects, such as operational activities, human resource management activities and business financial activities are still of low quality.

6. Operational activities in producing coconut shells, producers do not diversify their products and each producer only produces one kind of product that is the same as other producers, and the producers are satisfied with the coconut shell products they produce.

7. Human resource management activities, existing workers tend to only do the work assigned to them without any desire to create product diversification.

8. Business financial activities, the capital used is still limited because in general coconut shell producers still rely on their own capital to run their business.

9. On the other hand, the profit of the coconut shell producers is still low. This is because of the low productivity of coconut shell agro-industries in the assisted subjects, so that they need guidance and empowerment.

\subsection{The Process of Empowering Coconut Shells in Wager Hamlet, Sukosari Village, Kasembon District Mentoring planning}

This planning is carried out after paying attention to the real conditions in the community using a SWOT analysis. The process of identifying problems in the community and analyzing the strengths, weaknesses, challenges and opportunities is done by involving the community in Wager Hamlet, Sukosari Village, Kasembon District. This planning includes community strategies and methods in solving problems faced by community of Wager hamlet, Sukosari Village, 
Kasembon District. Especially, Since all businesses (especially large) have theirbsuppliers from whom they buy either materials or products, the quality that they provide them is able to affect the overall quality of the finished products [6]. As organisations is considered to be one of the most admired and robust operations management tool which despite of several criticism attained colossal importance from both academic and industry [7]; [8]; [9]; [10]; [11]; [12]; [13].

Researchers collected data on the condition of the community of Wager Hamlet, Sukosari Village, Kasembon District in general through interviews with the Village Head, DMI, Posdaya Chair, and Chair of caretaker of Baiturrahman Mangir Mosque about general conditions in the research area, in the form of population data, age of the population, livelihoods of the population, and geographic data of the research area, namely the community of Wager Hamlet, Sukosari Village, Kasembon District. In addition, in this interview, information was also extracted about the potentials that could be developed in the community of Wager Hamlet, Sukosari Village, Kasembon District as a form of development of the existing mosque-based Posdaya. Interviews were conducted twice, in order to clarify the validity of the data obtained, so that the treatment carried out by researchers with the people of Wager Hamlet, Sukosari Village, Kasembon District was as needed.

In the next stage, the researchers collected data through the Forum Group Discussion (FGD), which was attended by community stakeholders from Wager Hamlet, Sukosari Village, Kasembon District, which consisted of RW (the division of regions in Indonesia under the Village) heads, RT (the lowest administrative division of Indonesia) heads, Karang Taruna (youth organization of the village) leaders, religious leaders, figures Community, Chairperson of Posdaya, Chairman of $\mathrm{T}$ caretaker of Baiturrahman Mangir Mosque, and DMI.

The data collected through the Forum Group Discussion (FGD) is in the form of identification of potentials that can be developed, especially the development of local potential, especially with regard to coconut shells related to the supply of raw materials to the marketing of processed coconut shell handicraft products, as well as accommodating their aspirations.

Based on the above, the forms of activities to be carried out in this action research include:

1. A joint business group was formed in an organizational forum (FGD) Forum Group Discussion, as a form of cooperation between coconut shell producers in obtaining information related to the supply of raw materials to marketing of processed coconut shell handicraft products, as well as accommodating their aspirations.
2. Workshop on the preparation of activities based on the results of the FGD. In this case, the result is training in coconut shell craft processing.

3. Making coconut shell craft processing assistance modules.

\subsection{Implementation of Mentoring Activities}

After the planning process was carried out, the community of Wager Hamlet, Sukosari Village, Kasembon District implemented the plan that had been made with the assistance and facilitation of the researcher.

Based on the above, the forms of activities carried out in this action research are:

Periodic training based on the program launched, namely coconut shell craft processing training, which was conducted first, on Sunday November 12015 , starting at 09.00 A.M to 16.00 P.M at Baiturrahman Mangir Mosque, Wager Hamlet, Sukosari Village, Kasembon District.

Community mentoring is based on the program launched, which takes the form of developing local potential with training in coconut shell craft processing, as well as building the entrepreneurial mentality of congregations and residents of the Baiturrahman Mangir Mosque in Wager Hamlet, Sukosari Village, Kasembon District.

Community assistance is based on the program launched, which takes the form of developing local potential with training in coconut shell craft processing, as well as building the entrepreneurial mentality of congregations and residents of the Baiturrahman Mangir Mosque in Wager Hamlet, Sukosari Village, Kasembon District. In their initial activities, the congregation and residents are built their business mentality with directives and real examples, people or groups of people who are successful in entrepreneurship, especially by processing materials that are considered useless, become efficient. In this initial activity, apart from being accompanied by a research team, chaired by M. Fahim Tharaba, with members Yuniarti Hidayah Suyoso Putra and Nurul Yaqien, he was also accompanied by a team of experts, known to Mu'arifatul Jannah, as the main guide, as well as providing direct training to congregations. and residents of the Baiturrahman Mangir Mosque, Wager Hamlet, Sukosari Village, Kasembon Sub-district, relating to the development of local potential by training coconut shell craft processing by introducing and showing the processed coconut shell basic ingredients, such as coconut shell tissue boxes, coconut shell bags, key chains coconut shells, coconut shell brooches, coconut shell drinking containers, coconut origin 
products, etc. As a sample, the method of making coconut shell tissue is practiced.

All processes and activity cycles are carried out by the research subjects, researchers, observed, monitored and evaluated.

\subsection{Obstacles Encountered}

In mentoring residents in the form of developing local potential with training in coconut shell craft processing, as well as building the entrepreneurial mentality of the congregation and residents of the Baiturrahman Mangir Mosque in Wager Hamlet, Sukosari Village, Kasembon District, observations are always made to observe and analyze their strengths, weaknesses, challenges and opportunities and are carried out also reflection (reflection) on the efforts that have been made by the people of Wager Hamlet, Sukosari Village, Kasembon District. This reflection and evaluation culminates in a plan such as in the first point to complete the problems that exist in the community, whether it has not been completed in the first stage or to solve new problems, until it reaches the people of Wager Hamlet, Sukosari Village, Kasembon District who are peaceful, prosperous, happy, loving and supportive, who are independent.

The obstacles faced include:

1. The entrepreneurial mentality of congregations and residents of the Baiturrahman Mangir Mosque in Wager Hamlet, Sukosari Village, Kasembon District.

2. Development of collective entrepreneurship among congregations and residents of the Baiturrahman Mangir Mosque in Wager Hamlet, Sukosari Village, Kasembon District, most of whom are still private entrepreneurs.

3. Capital in developing entrepreneurship for congregations and residents of the Baiturrahman Mangir Mosque in Wager Hamlet, Sukosari Village, Kasembon District.

4. Diversification of products from congregations and residents of Baiturrahman Mangir Mosque, Wager Hamlet, Sukosari Village, Kasembon District.

5. Marketing of products of congregation and residents of the Baiturrahman Mangir Mosque in Wager Hamlet, Sukosari Village, Kasembon District.

\subsection{Problem Solving Strategies}

The constraints found in the field above, the researcher used the following problem-solving strategies:

1. The entrepreneurial mentality of congregations and residents of the Baiturrahman Mangir Mosque in Wager Hamlet, Sukosari Village, Kasembon District. Providing training and development to build Islamic entrepreneurial mentality, as a solution.

2. Development of collective entrepreneurship among congregations and residents of the Baiturrahman Mangir Mosque in Wager Hamlet, Sukosari Village, Kasembon District, most of whom are still private entrepreneurs. Developing (FGD) Forum Group Discussions, in the development of a more advanced and promising collective entrepreneurship with the spirit of fraternity, as a solution.

3. Capital in developing entrepreneurship for congregations and residents of the Baiturrahman Mangir Mosque in Wager Hamlet, Sukosari Village, Kasembon District. Developing (FGD) Forum Group Discussions, in developing a more advanced and promising collective entrepreneurship with the spirit of fraternity and introducing existing SMEs (Small and Medium-Sized Enterprises) as a solution.

4. Diversification of products from congregations and residents of Baiturrahman Mangir Mosque, Wager Hamlet, Sukosari Village, Kasembon District. Providing training and product diversification development, especially coconut shell processed products, as a solution.

5. Marketing of products of congregation and residents of the Baiturrahman Mangir Mosque in Wager Hamlet, Sukosari Village, Kasembon District. Developing (FGD) Forum Group Discussions, in developing a more advanced and promising collective entrepreneurship with the spirit of fraternity and introducing existing SMEs (Small and Medium-Sized Enterprises), among others, helping to market through these SMEs (Small and Medium-Sized Enterprises), as a solution.

\subsection{Changes and Empowerment Results of Coconut Shells in Wager Hamlet, Sukosari Village, Kasembon District}

Agro-industrial development is a continuation of agricultural development [14]. This has been proven that agro-industry is able to increase the income of agribusiness actors [15], is able to absorb labor, is able to increase foreign exchange earnings, and is able to encourage the emergence of other industries [16]. Agroindustrial development is a very important effort to achieve several goals, namely attracting and encouraging the emergence of new industries in the agricultural sector, creating a strong economic structure, creating added value, creating jobs, and increasing foreign exchange earnings [2].

The agro-industry which is estimated to increase the income of agribusiness actors is the plantation agroindustry. This is considering that the plantation agroindustry is relatively directly connected to farming. One of the plantation agro-industries whose existence has got 
a place in the community is the agro-industry which processes coconut shells taken from coconut trees into handicraft products from coconut [17].

Coconut is one of the most common agricultural commodity crops in Indonesia. This plant belongs to the palmae family or palms and thrives in temperate to hot climates. The coconut commodity is considered very beneficial for the community with all its forms of diversification. Coconut plant has many benefits, from roots to its stems. Coconut roots can be used for crafts, and firewood; coconut trunks can be made for building materials or various kinds of handicraft products such as water furniture, wall hangings, and various other crafts; coconut flowers that are called manggar and mancung can be used for various kinds of handicraft products, such as wall hangings, and firewood; the meat of the coconut can be processed into copra for the needs of the coconut oil industry, srondeng (Indonesian traditional food made from grated coconut and fried until golden brown with specific spices), pon pon mendut (Indonesian traditional snack which the filling is made from grated coconut mixed with brown sugar), coconut milk or coconut meal and other products made from the meat of coconut; coconut water can be used for various kinds of processed food or food ingredients like iced young coconut and nata de coco. Consuming coconut water or extract of coconut water is also very good for health of which can maintain the body's metabolism, prevent stroke, treat poisoning, and maintain stamina of body and kidneys, and even increase the health of the fetus. Next, the coconut skin or especially the husk can be used for various kinds of handicraft products, such as wall hangings, doormats, brooms, and firewood. The last is the shell of the coconut can be used for various kinds of handicraft products, such as wall hangings, water scoops, cups, saucers, key chains, beads, coconut embryos in scouts and firewood [3].

In its development, coconut produced a lot of waste, one of which is coconut shell. Processed coconut shell waste is considered more profitable than selling only raw coconut shells. So the efforts of farmers in the agroindustry to diversify the processed coconut shell into coconut handicrafts have a very important role in increasing income and business opportunities and potential to be developed. The coconut shell itself is a coconut shell which becomes waste from the coconut fruit.

Coconut shell agro-industry is one form of agroindustry which is mostly operated on a household scale. So that the coconut shell agro-industry has not been able to play a maximum role.

According to information from the DMI (Indonesian Mosque Council) Kasembon District and also the mosque-based Posdaya volunteer, Avicena, The number of coconut shells in Wager Hamlet, Sukosari Village,
Kasembon District, is very abundant. It is estimated that each house has a pile of coconut shells on a truck and there are around 200 families, which only opened split the coconut shells and sold directly to middlemen. Therefore, with the increase in processed coconut shell handicrafts, it is hoped that it can encourage the development of coconut shell agro-industries. So that it can increase the profits of this coconut shell producer later. However, the agro-industry is experiencing obstacles, namely coconut shell producers find it difficult to improve the quality and quantity of coconut shell production and marketing.

In Malang Regency, especially in Wager Hamlet, Sukosari Village, Kasembon District, The coconut shell agro-industry is expected to develop due to the availability of abundant natural resources of coconut shells as raw material for the manufacture of processed coconut handicrafts. According to Anonymous [4], the Malang Regency government determines coconut as a raw material for potential superior products that can improve the economy in the Malang Regency. It can be seen from the number of home industries that use derivatives from coconut as raw material, namely coconut sugar. The use of coconut sugar is around 9,142 business units, where in the central area there are 8,818 business units and 324 business units in non-central areas. The production of printed coconut sugar in each area reaches around 40-50 tons per day, not yet other processed coconut products. This data shows how coconut is the main priority, which of course the waste, including coconut shells, is also the same.

However, in developing coconut shell agroindustry, it is still faced with several obstacles, such as limited capital, limited skills of the workforce, and lack of management knowledge in running a business. This indirectly causes the quantity and quality of coconut shell production to be low so that the profit obtained by coconut shell producers is low.

Coconut shell agro-industry in Wager Hamlet, Sukosari Village, Kasembon District is one of the coconut shell agro-industry centers in Malang Regency, and it can be said that the largest supply of coconut shells is in Wager Hamlet, Sukosari Village, Kasembon District. This coconut shell agro-industry has been running for a long time and is still going on until now.

However, most coconut shell agro-industries in the area are still operated on a household scale and the production process is still done traditionally. So that the quantity and quality of coconut shell production is still low. In fact, the demand for coconut shells from household and industrial consumers continues to increase along with the increasing population and the development of the industrial sector [18]. 
In this case, what causes the quantity and quality of coconut shell production to be produced is still low, namely it is known from several activities in the coconut shell agro-industry such as operational activities, human resource management activities and business financial activities. For operational activities in producing coconut shells, producers do not diversify their products. Each manufacturer only produces one kind of product which is the same as other manufacturers. This is because the producers are satisfied with the coconut shell products they produce.

For human resource management activities, the existing workforce tends to only do the work assigned to it without any desire to be able to create product diversification. So that coconut shell producers find it difficult to improve the quality of the resulting production. Meanwhile, in business financial activities, the capital used is still limited because in general coconut shell producers still rely on their own capital to run their business. With this limited capital, it is difficult for producers to increase the quantity of coconut shell production, so that it can affect the profits obtained by coconut shell producers.

\subsection{Coconut Shell Agroindustry Development Model Framework}

This coconut shell agro-industry can develop because it has the potential, namely the availability of human resources as labor and natural resources of coconut which is the raw material in the coconut shell processing process. However, in its development the coconut shell agro-industry still has several obstacles including limited capital, limited skills of labor and lack of knowledge about management in running a business. Where it can affect the quantity and quality of coconut shell handicrafts produced.

To solve the problem of agro-industrial productivity, it is necessary to identify activities that are competitive advantages in this agro-industry, namely primary activities and supporting activities [19]. The primary activities consist of inward logistics, operations, outward logistics, marketing and sales, services. Meanwhile, supporting activities consist of purchasing, technology development, human resource management, and company infrastructure.

Inward logistics are activities associated with receiving, storing and distributing inputs to products. Operations are activities associated with converting inputs into final products. Outbound logistics are activities related to the collection, storage and physical distribution of products to buyers. Marketing and sales are activities related to providing the means that can be used by buyers to buy products and influence them to buy. Meanwhile, service is an activity related to the provision of services to increase or maintain product value.

Purchasing refers to the input purchasing function used in the company's value chain, the input purchased includes raw materials, auxiliary materials and complementary materials. Technology development is an activity related to efforts to improve products and processes. Human resource management consists of activities involved in recruiting, hiring, training, developing and compensating for all types of personnel. Meanwhile, company infrastructure consists of several activities including general management, planning, finance, law and government affairs.

From these activities, it is expected that primary and supporting activities will run well. So that the coconut shell agro-industry has a high added value, so that later it can increase the profits of the coconut shell handicraft processed agro-industry producers. Systematically, the framework of thought above can be explained in Figure 1.

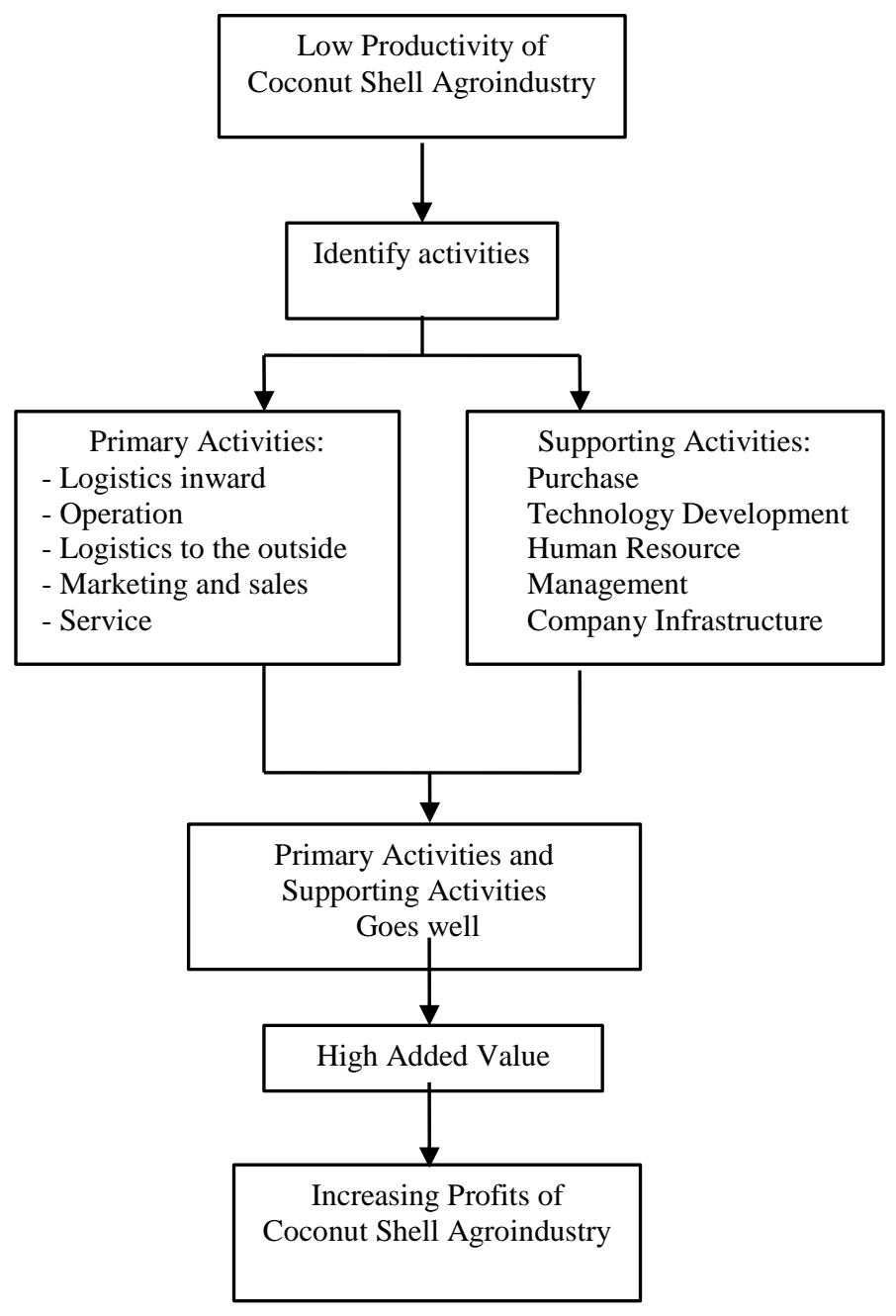

Figure 1. Coconut Shell Agroindustry Development Model 


\subsection{Analysis of Local Potential Development with Coconut Shell Craft Processing Training, While Building the Entrepreneurial Mentality of Congregation and Residents of Baiturrahman Mangir Mosque, Wager Hamlet, Sukosari Village, Kasembon District}

In mentoring residents in the form of developing local potential with training in coconut shell craft processing, as well as building the entrepreneurial mentality of the congregation and residents of the Baiturrahman Mangir Mosque in Wager Hamlet, Sukosari Village, Kasembon District, observations are always made to observe and analyze their strengths, weaknesses, challenges and opportunities and are carried out also reflection on the efforts that have been made by the people of Wager Hamlet, Sukosari Village, Kasembon District. This reflection and evaluation culminates in a plan such as in the first point to complete the problems that exist in the community, whether it has not been completed in the first stage or to solve new problems, until it reaches the people of Wager Hamlet, Sukosari Village, Kasembon District who are peaceful, prosperous, safe, mawadah and full of grace, who are independent.

Likewise, the training also built the entrepreneurial mentality of the congregation and residents of the Baiturrahman Mangir Mosque in Wager Hamlet, Sukosari Village, Kasembon District, as can be seen in the picture below.

\subsection{Analysis of Training and Development to Build Islamic Entrepreneurial Mental}

In terms of this assistance, mental training for the entrepreneurial courage of congregations and residents of the Baiturrahman Mangir Mosque in Wager Hamlet, Sukosari Village, Kasembon District, is carried out by holding training and developing Islamic entrepreneurial mentality, and the solution.

\subsection{Analysis Forum Group Discussion (FGD), In the Development of a More Advanced and Promising Collective Entrepreneur with the Spirit of Fraternity}

In terms of this assistance, the development of collective entrepreneurship between congregations and residents of the Baiturrahman Mangir Mosque of Wager Hamlet, Sukosari Village, Kasembon District, most of which are still private entrepreneurs, is by developing (FGD) Forum Group Discussions, in developing more advanced and promising collective entrepreneurship with the spirit of ukhuwah, as a solution.

\subsection{Analysis (FGD) Forum Group} Discusssion, In the Development of More Advanced and Promising Collective Entrepreneurs with the Spirit of Fraternity and Introducing SMEs

In terms of this assistance, the development of collective entrepreneurship between congregations and residents of the Baiturrahman Mangir Mosque of Wager Hamlet, Sukosari Village, Kasembon District, which is related to capital is the development (FGD) Forum Group Discussion, in developing more advanced and promising collective entrepreneurship with the spirit of fraternity and introduce the existing SMEs, as a solution.

\subsection{Analysis of Training and Development of Coconut Shell Processed Product Diversification}

In terms of this assistance, the development of product diversification from congregations and residents of the Baiturrahman Mangir Mosque in Wager Hamlet, Sukosari Village, Kasembon District is by holding training and developing product diversification, especially processed coconut shells, as a solution.

\subsection{Marketing Analysis Through SMEs}

In terms of this assistance, the development of marketing for the products of congregations and residents of the Baiturrahman Mangir Mosque in Wager Hamlet, Sukosari Village, Kasembon District is to develop (FGD) Forum Group Discussions, in developing more advanced and promising collective entrepreneurship with the spirit of ukhuwah and introducing existing SMEs, among others, help market through these SMEs, as a solution.

The impact of training and mentoring is that after the action research program was carried out, changes occurred, namely (1) Added value and benefits to coconut shell agro-industrial products. (2) The availability and skill of Human Resources (HR) as processing workers for coconut shell agro-industrial products. (3) Increased knowledge of management in running a business, which can affect the quantity and quality of coconut shell handicrafts produced. (4) Increased knowledge of the importance of having a competitive advantage in coconut shell agro-industries, marketing and sales, services, technology development, human resource management, and infrastructure. (5) The creation of an established life, so that religious life becomes cool and peaceful, full of a sense of togetherness and tolerance. And (6) Creating of happy, loving and supportive family to creat ذرية قرة اعين by competitive advantage and comparative advantage [20], [21], reference to Rasulullah SAW. [22]. 


\section{CONCLUSION}

After this action research program was carried out, there were changes, namely

1. Added value and benefits to coconut shell agroindustrial products.

2. The availability and skill of Human Resources (HR) as processing workers for coconut shell agro-industrial products.

3. Increased knowledge of management in running a business, which can affect the quantity and quality of coconut shell handicrafts produced.

4. Increased knowledge of the importance of having a competitive advantage in coconut shell agro-industries, marketing and sales, services, technology development, human resource management, and infrastructure.

5. The creation of an established life, so that religious life becomes cool and peaceful, full of a sense of togetherness and tolerance.

6. The creation of a happy, loving and supportive family.

\section{REFERENCES}

[1] M. F. Tharaba, Penelitian Penguatan Posdaya berbasis Masjid Kecamatan Bantur, Kabupaten Malang. Research Report. Lembaga Penelitian dan Pengabdian Kepada Masyarakat (LP2M) UIN Maulana Malik Ibrahim. (Unpublished), 2017

[2] Soekartawi. Pengantar Agroindustri, Jakarta: PT. Raja Grafindo Persada, 2001

[3] Anonymous, Strategi Pengembangan Agroindustri Gula Kelapa di Kabupaten Cilacap. Available at http://pasca - unsoed.or.id/ (verified 26 Februari 2008), 2006

[4] Anonymous, Profil Gula Kelapa. Available at http://www.kabblitar.go.id/ (verified 9 Februari 2008), 2005

[5] M. F. Tharaba, Mukhibat, "The Islamic Education Reform_Early $20^{\text {th }}$ Century", at-Tahrir, Jurnal Pemikiran Islam, 20(1) 2020 pp. 121-141, DOI : 10.21154/altahrir.v20i1.2008

[6] M. Vranakia, S. Vranakisa, and L. Sarigiannidis, "Total Quality Management Implementation in Greek businesses: Comparative assessment 20092013", International Journal of Production Management and Engineering, 3(2) 2015 87-95.

[7] R. Basu and P. Bhola, "Exploring Quality Management Practices and Its Pattern Analysis in Indian Service SMEs", Journal of Enterprising
Culture, 23(2) 2015 199-235. DOI: $10.1142 / \mathrm{S} 0218495815500077$.

[8] L. Ritchie, and B.G. Dale, "Self Assessment Using The Excellence Model: A Study Of Practice And Process", International Journal of Production Economics, 66(3) 2000 241-254. DOI: https://doi.org/10.1016/S0925-5273(99)00130-9

[9] R. Sousa and C.A. Voss, "Quality Management ReVisited: A Reflective Review and Agenda for Future Research", Journal of Operations Management, 20(1) 2002 91-109. DOI: https://doi.org/10.1016/S0272-6963(01)00088-2

[10] E. Claver, J.J. Tari, and J.F. Molina, "Critical Factors and Results of Quality Management: an Empirical Study", Total Quality Management and Business Excellence, 14 (1) 2003 91-118.

[11] H. H. Chang, "Development of Performance Measurement Systems in Quality Management Organizations", The Service Industries Journal, 26(7) 2006 765-786.

[12] S.I. Salaheldin, "Critical Success Factors for TQM Implementation and Their Impact on Performance of SMEs", International Journal of Productivity and Performance Management, 58(3) 2009 215-237.

[13] M. Kumar, T.K. Fong, and A. Manshor, "Determining The Relative Importance of Critical Factors in Delivering the Service Quality of Banks: An Application of Dominance Analysis in SERVQUAL Model," Managing Service Quality: An International Journal, 19(2) 2009 211-228.

[14] Soeharjo. 1991. Konsep dan Ruang Lingkup Agroindustri. Jakarta: DIKTI, 1991

[15] A. Aziz, Agroindustri Buah - buahan Tropis. PPA CIDESUQ. Jakarta, 1993

[16] Supriyati. Peranan, Peluang dan Kendala Pengembangan Agroindustri di Indonesia. Available at http://pse.litbang.deptan.go.id/ (verified 15 Februari 2008), 2006

[17] N. Rohanan, Tradisi Masyarakat Banjar-Ciamis dalam Pembuatan Gula Kelapa Secara Sederhana yang Memberikan Tambahan Pendapatan bagi petani. Available at http://database.deptan.go.id:8081/saims-indonesia/ (verified 14 Februari 2008), 2006

[18] N.A.R. Hanani, et al, Strategi Pembangunan Pertanian. Yogyakarta: Lappera Pustaka Utama, 2006

[19] M. E. Porter, Keunggulan Bersaing, Menciptakan dan Mempertahankan Kinerja Unggul. Jakarta: Binarupa Aksara, 1994 
[20] M. F. Tharaba, Membangun Budaya Mutu sebagai Implementasi Penjaminan Mutu dalam Pengembangan Pendidikan Islam di Indonesia. Presented at The 1st Annual Conference on Islamic Education Management (ACIEM) Islamic Education Management for Millineal Generation; Quality and Competitiveness, 2019
[21] M. F. Tharaba, "Manajemen Pendidikan Islam Analisis Teori Pedadogik dan Andragogik". J-MPI: Jurnal Manajemen Pendidikan Islam, 4 (1) 201920 29

[22] M. F. Tharaba, "Membangun Peradaban dengan Konsep Muttaqin dan Imama”. Jurnal Manajemen Pendidikan Islam (J-MPI), 2 (2) 2017 107-113. 